\title{
Interaction of Formal and Informal Financial Markets in Quasi-Emerging Market Economies*
}

\author{
Harold P.E. Ngalawa ${ }^{\dagger}$ \\ University of Cape Town
}

September 15, 2009

\begin{abstract}
The primary objective of this paper is to investigate the interaction of formal and informal financial markets and their impact on economic activity in quasi-emerging market economies (QEMEs). Using a four-sector dynamic stochastic general equilibrium (DSGE) model, we demonstrate that formal and informal financial sector loans are complementary in the aggregate, suggesting that an increase in the use of formal financial sector (FFS) credit creates additional productive capacity that requires more informal financial sector (IFS) credit to maintain equilibrium. Our model also demonstrates that the response of FFS loans to a positive production technology shock is sensitive to the rate of success for high risk borrowers while the response of IFS loans is not. We further show that interest rates in the IFS may not necessarily be driven by FFS interest rates, with the implication that the impact of monetary policy on economic activity may partly be offset by IFS interest rates.
\end{abstract}

\section{Introduction}

One of the fundamental distinguishing features of quasi-emerging market economies (QEMEs) is the co-existence of formal and informal financial sectors. Within the two broad market segments, there are several different types of operators that usually have very little contact with one another and whose clients often do not overlap; and even when they overlap, they are able to sort out clearly which aspects of their financial business will be handled by which financial arrangement (Aryeetey, 2008). Unfortunately, nearly all QEMEs leave out informal

${ }^{*}$ This paper is part of a PhD Thesis in progress. I thank Professor Nicola Viegi, my supervisor, for his useful comments. Any errors are my responsibility, though.

†hngalawa@yahoo.co.uk/ Harold.Ngalawa@uct.ac.za 
financial transactions in official monetary data, effectively underestimating the volume of financial transactions and bringing into question the timing and effect of monetary policy.

A number of studies have shown that the informal financial sector (IFS) is large (see for example African Development Bank, 1994; Chipeta and Mkandawire, 1991) and growing (see for example Chipeta, 1998; Soyibo, 1997; Bagachwa, 1995; Aryeetey, 1994; Chipeta and Mkandawire, 1991) in most QEMEs. Given its sheer size, the response of the IFS to policy is clearly non-trivial, and may vary depending on whether the informal markets are autonomous or reactive to formal financial markets (See Rahman, 1992; Acharya and Madhura, 1983; Sundaram and Pandit, 1984); whether the two markets are competitive or complementary; and whether the nature of their interaction frustrates or strengthens monetary policy. This paper sets out to investigate these and other issues.

For many years, informal financial markets have been perceived as an economic ill that has only succeeded in exploiting impoverished peasants in QEMEs (Bolnick, 1992). The policy prescription, as expected, has been to integrate the IFS in the formal financial sector (FFS) (see Aryeetey, 2008; Bolnick, 1992; Bell, 1990). Recent research, however, has shown an emerging change in opinion with the sector now being positively regarded as an integral component of the whole financial sector. Chipeta and Mkandawire (1991), for instance, report that the IFS in Malawi is playing an important role in alleviating economic hardships among low-income groups by enabling these groups mobilise resources (savings effect), use the resources to earn income (investment effect) and obtain loans (credit effect). An account of similar findings is presented by Steel, Aryeetey, Hettige and Nissanke (1997) in a study of Ghana, Malawi, Nigeria and Tanzania. Steel et al. (1997) stress that informal financial institutions (IFIs) in the three countries are an important vehicle for mobilising household savings and financing small businesses, a function that is carried out using specialized techniques that address the problems of information, transaction costs and risks, which prevent banks from serving these market segments. In Kenya, Atieno (2001) observes that unlike commercial banks, informal credit sources provide easier access to credit facilities for small and micro-enterprises.

The importance of the IFS in QEMEs is also underlined by its size. According to the African Development Bank (1994), 70 percent of the total population in Cameroon and 80 percent in Zambia take part in informal financial activities; 85 percent of rural households in Niger and over 80 percent of smallholder farmers in Zimbabwe have access to informal credit; and, 60 percent of the population in Ethiopia and 52 percent in Senegal participate in rotating savings and credit associations (ROSCAs). In Malawi, Chipeta and Mkandawire (1991) observed that in 1989, the IFS was larger than the FFS when measured in terms of the ratio of credit extended by the IFS to the private sector to credit extended by the 
formal and semi-formal financial sector to the same sector. They arrived at the same result by comparing savings mobilised by the formal and informal financial sectors. A number of studies also suggest that the IFS may not only be large, but growing as well. Field surveys carried out in Nigeria by Soyibo (1997), in Ghana by Aryeetey (1994), in Malawi by Chipeta and Mkandawire (1991) and in Tanzania by Bagachwa (1995) established that the IFS grew faster than the FFS in the reform years 1990-1992 (Chipeta, 1998).

Against this background, it is clear that official monetary data grossly underestimates the volume of financial transactions in QEMEs; and that operating tools of monetary policy are targeted at only a portion of the financial sector though their impact may spread to the whole sector. To this point, important questions with profound policy implications ought to be asked. How do formal and informal financial markets interact? How does this interaction affect economic activity? How do informal financial markets respond to monetary policy and what is the impact on economic activity? This study contributes to the literature by providing answers to these and related questions using a four-sector dynamic stochastic general equilibrium (DSGE) model incorporating asymmetric information in the FFS.

The choice of a DSGE framework for analysis has been motivated by a number of factors. First, DSGE models are derived from microeconomic principles of constrained decisionmaking. That is, they describe the general equilibrium allocations and prices of the economy in which all agents dynamically maximise their objectives subject to budget or resource constraints (Tovar, 2008). Following the estimation of deep parameters, it is possible to avoid the Lucas Critique, where only models in which the parameters that do not vary with policy interventions are suited to evaluate the impact of policy change (Ibid, 2008). Indeed, according to Woodford (2003), DSGE models should not, at least in principle, be vulnerable to the Lucas Critique, unlike the more traditional macroeconomic forecasting models. Second, DSGE models are structural, implying that each equation has an economic interpretation which allows clear identification of policy interventions and their transmission mechanisms (Peiris and Saxegaard, 2007). Third, DSGE models are forward looking in the sense that agents optimise model-consistent forecasts about the future evolution of the economy (Ibid, 2007). And fourth, DSGE models allow for a precise and an unambiguous examination of random disturbances. This is facilitated by the stochastic design of the models. To the best of our knowledge, there is no study that has examined the interaction of formal and informal financial sectors and their impact on economic activity in QEMEs using a macromonetary model developed within the context of a microfounded DSGE representation.

Following this introduction, the rest of the paper is structured as follows. A DSGE model for QEMEs is developed in Section 2. The model aims at building a quantitative macroeconomic representation from explicit optimising behaviour while allowing for a minimum amount pos- 
sible of imperfections. Thus, the model is similar in many aspects to the Real Business Cycle (RBC) approach except on the monetary side (see Tovar, 2008; Mankiw, 2006). Section 3 presents calibrations of parameter and steady state values; outlines and interprets simulation results of the baseline model in the event that a positive shock in production technology and a monetary policy shock within the context of a forward-looking monetary policy rule; and carries out a comparative analysis of sample moments from the simulations model and those obtained from actual data of selected QEMEs and industrial economies. A summary and conclusion follow in Section 4.

\section{A DSGE Model for QEMEs}

\subsection{Basic Design}

There are four sectors in the economy: households, firms, financial intermediaries and monetary authorities. The household maximises an intertemporal utility function separable in consumption, leisure, and real cash balances; and its financial resources are used for consumption or held as cash balances with the excess deposited in commercial banks or lent out to firms in the informal credit market. We describe the household's credit function as 'moneylending' and we reserve the term 'moneylenders' for credit institutions in the IFS. Thus, we assume that the behaviour of moneylenders is described within the household's utility maximisation problem. The firm produces its own capital by converting loans obtained from the formal or informal financial sectors, which are assumed to be perfect substitutes (see Dasgupta, 2004). Using capital and labour as the only factors of production, the firm produces final output using technology described by a Cobb Douglas production function. In the financial market, firms self-selectively seek loans either in the formal or informal credit markets.

While lenders in the IFS deal with local communities for which they are able to identify risk levels of individual potential borrowers, the same does not apply to commercial banks in the FFS. Commercial banks are unable to distinguish between high and low risk borrowers ex-ante because high risk borrowers disguise themselves as low risk borrowers in order to enhance their chances of obtaining credit. We assume banks have a preference for low risk borrowers because they are associated with relatively higher expected profits while high risk borrowers tend to lower expected profits. At this point, we invoke the Stiglitz and Weiss (1981) hypothesis that banks may ration credit in equilibrium. The residual demand that is rationed out of the formal loan market spills over to the informal credit market. Accordingly, the IFS provides credit to this demand as well as the component of total credit demand which 
self selectively seeks loans in the IFS only. Finally, we assume that the population is constant so there is no aggregation bias with treating average quantities as aggregate quantities (see Dasgupta, 2004).

\subsection{Household Sector}

There is a continuum of identical households (with identical endowments and preferences). We ignore population growth and consider a representative household of constant size with a constant amount of time per period and an infinite planning horizon. The objective of the household is to maximise the expected sum of a discounted stream of instantaneous utilities $U_{t}$ given $b^{1}$ :

$$
\max E_{0} \sum_{t=0}^{\infty} \beta^{t} U_{t}
$$

where $\beta \epsilon(0,1)$ is the consumer subjective intertemporal discount factor. The utility function is assumed to be separable in consumption $\left(C_{t}\right)$, leisure $\left(1-N_{t}\right)$ and real cash balances $\left(\frac{M_{t}}{P_{t}}\right)$ :

$$
U_{t}=\ln C_{t}+\Phi \ln \left(1-N_{t}\right)+\Gamma \ln \left(\frac{M_{t}}{P_{t}}\right)
$$

where $N_{t}$ is time $t$ labour (the amount of time worked) and $\Phi, \Gamma>0$ represent the importance of leisure and real cash balances, respectively, in utility. The utility function $U_{t}(., .,$.$) satisfies$ $U_{t, C_{t}}>0, U_{t,\left(1-N_{t}\right)}>0, U_{t,\left(\frac{M_{t}}{P_{t}}\right)}>0, U_{t, C_{t}, C_{t}}<0, U_{t,\left(1-N_{t}\right),\left(1-N_{t}\right)}<0$ and $U_{t,\left(\frac{M_{t}}{P_{t}}\right),\left(\frac{M_{t}}{P_{t}}\right)}<0$. The household's financial resources are used for consumption, deposited in commercial banks, held in cash or lent out to firms. We assume the household lends money to firms or deposits funds in commercial banks from its own earnings. Maximisation of the household's objective function, therefore, is subject to the following intertemporal budget constraint:

$$
C_{t}+L_{t}^{i}+D_{t}+\frac{M_{t}}{P_{t}}=\left(1+R_{t-1}^{l i}\right) q L_{t-1}^{i}+\left(1+R_{t-1}^{d f}\right) D_{t-1}+\frac{M_{t-1}}{P_{t-1}}+W_{t} N_{t}
$$

where $L_{t}^{i}$ are loans to firms given by households (informal finance), which we generalise as moneylending, $D_{t}$ are the household's deposits in commercial banks, $R_{t}^{l i}$ are interest rates on credit given by the households, $q_{t}$ is the probability of repayment on loans given by the moneylenders, $R_{t}^{d f}$ are interest rates on deposits in commercial banks and $W_{t}$ is the wage rate. Maximising the objective function given in equation (1) subject to the budget constraint in equation (3) with respect to consumption, labour, cash balances, and the household's loans

\footnotetext{
${ }^{1}$ A summary of parameters and variable definitions is presented in Appendix 1, Table 1.
} 
to firms and deposits in commercial banks, yields the following first order conditions:

$$
\begin{aligned}
\frac{1}{C_{t}} & =\beta\left(1+R_{t}^{d f}\right) E_{t}\left(\frac{1}{C_{t+1}}\right) \\
N_{t} & =1-\frac{\Phi C_{t}}{W_{t}} \\
\frac{M_{t}}{P_{t}} & =\Gamma \beta E_{t}\left(\frac{C_{t+1}}{R_{t}^{d f}}\right) \\
1+R_{t}^{d f} & =\left(1+R_{t}^{l i}\right) q
\end{aligned}
$$

Equation (4) is the Euler equation ${ }^{2}$. Equation (5) is a labour supply equation. It illustrates that consumption and labour supply are inversely related due to decreasing marginal utility of consumption. Equation (6) is a money demand equation. It states that the demand for real cash balances is negatively related to interest rates and positively related to future consumption. Equation (7) states that for the household in equilibrium, the effective return on deposits in commercial banks is equal to the return on loans given out on the informal financial market, taking into account the risk of default.

\subsection{The Firm}

A representative firm borrows from either the formal or informal financial sector in the current period and converts the loan into capital over a single period using a linear function described $\mathrm{as}^{3}$ :

$$
K_{t}=\vartheta_{\tau, t-1}\left(L_{t-1}^{f}+L_{t-1}^{i}\right)
$$

where $\vartheta_{\tau}$ is a risk factor or probability of success $(\forall \tau=h r, l r$, where $h r$ denotes high risk (low probability of success) and $l r$ stands for low risk (high probability of success)); and $L_{t}^{f}$ and $L_{t}^{i}$ are formal and informal financial sector loans, respectively ${ }^{4}$. This is a case of a generic firm. A proportion $(\rho)$ of all firms are high risk borrowers and the remaining proportion

\footnotetext{
${ }^{2}$ This is also referred to in the literature as the intertemporal consumption function. We can replace $\left(1+R_{t}^{d f}\right)$ by $\left(1+R_{t}^{l i}\right) q$ for the same result.

${ }^{3}$ For simplicity, we assume that a firm cannot borrow from both sectors at any given time.

${ }^{4}$ We define high risk firms as those firms that have a lower probability of success in converting the loans into capital while low risk firms are defined analogously as those firms with a higher probability of success in converting their loans into capital (see Dasgupta, 2004)
} 
$(1-\rho)$ are low risk. Aggregate capital stock, therefore, is described as:

$$
\begin{aligned}
& K_{t}=\rho \vartheta_{h r, t-1}\left(L_{t-1}^{f}+L_{t-1}^{i}\right)+(1-\rho) \vartheta_{l r, t-1}\left(L_{t-1}^{f}+L_{t-1}^{i}\right) \\
& K_{t}=\left[\rho \vartheta_{h r, t-1}+(1-\rho) \vartheta_{l r, t-1}\right]\left(L_{t-1}^{f}+L_{t-1}^{i}\right)
\end{aligned}
$$

The firm's production technology is assumed to be given by a Cobb-Douglas formulation of the following form:

$$
Y_{t}=e^{A_{t}} K_{t}^{\alpha} N_{t}^{1-\alpha}
$$

where $Y_{t}$ is output; and $A_{t}>0$ captures technology, which is assumed to evolve according to a first order autoregressive process given by:

$$
A_{t}=\eta A_{t-1}+\varepsilon_{t}^{A}
$$

where $\varepsilon_{t}^{A}$ is independently and identically distributed (iid) with a standard deviation of $\sigma_{\varepsilon^{A}}$. We assume the installation of capital takes one period and there are no adjustment costs, suggesting that capital stock is predetermined at time $t$ (Ambler and Paquet, 1994). The equation of motion for the capital stock is given by:

$$
K_{t+1}=(1-\delta) K_{t}+I_{t}
$$

The firm's cost minimisation problem subject to satisfying market demand, therefore, is given by:

$$
\min _{K_{t}, N_{t}} W_{t} N_{t}+\left(1+R_{t}^{l f}\right) L_{t}^{f}+\left(1+R_{t}^{l i}\right) q L_{t}^{i}+\phi_{t}\left(Y_{t}-e^{A_{t}} K_{t}^{\alpha} N_{t}^{1-\alpha}\right)
$$

where $\phi_{t}$ is a Lagrangian multiplier. First order conditions with respect to labour, FFS loans and IFS loans yield demand functions for labour and formal and informal financial sector loans, in that order, given by: 


$$
\begin{aligned}
W_{t} & =\phi_{t}(1-\alpha) \frac{Y_{t}}{N_{t}} \\
L_{t}^{d f} & =\frac{1}{\vartheta_{\tau t}} E_{t}\left[\frac{(1-\alpha)\left(1+R_{t}^{l f}\right) K_{t+1}^{\alpha}}{\alpha \vartheta_{\tau t} W_{t+1} N_{t+1}}\right]^{\frac{1}{\alpha-1}} \\
L_{t}^{d i} & =\frac{1}{\vartheta_{\tau t}} E_{t}\left[\frac{(1-\alpha)\left(1+R_{t}^{l i}\right) q K_{t+1}^{\alpha}}{\alpha \vartheta_{\tau t} W_{t+1} N_{t+1}}\right]^{\frac{1}{\alpha-1}}
\end{aligned}
$$

Equation (14) shows that wages increase with output but are inversely related to labour supply. Equations (15) and (16) show the self-selection of firms in seeking loans. While some firms approach the FFS first, others self-selectively approach the IFS for credit. Both demand functions show that the demand for loans increases with higher expected wages and employment.

\subsection{Financial Intermediaries}

An important distinguishing feature of low income economies is the segmentation of the financial system into formal and informal financial sectors. Within the two broad segments, there are several different types of operators that usually have very little contact with one another and whose clients often do not overlap; and even when they overlap, they are able to sort out clearly which aspects of their financial business will be handled by which financial arrangement (Aryeetey, 2008). Our model of the financial sector is drawn in the spirit of Dasgupta (2004).

\subsubsection{Formal Financial Sector}

Base lending rates are set as a mark-up $(\zeta)$ over the bank rate i.e. $R_{t}^{l f}=R_{t}^{n r}+\zeta$, where $R_{t}^{n r}$ is the bank rate. The size of the mark-up depends on the commercial bank's market power, reflecting its estimate of the interest elasticity of the demand for credit (King, 2003). For simplicity, we assume the mark-up is fixed. Aggregate self-selection demand for loans in 
the FFS is given by:

$$
\begin{aligned}
L_{t}^{a d f}= & \frac{\rho}{\vartheta_{h r, t}} E_{t}\left[\frac{(1-\alpha)\left(1+R_{t}^{l f}\right) K_{t+1}^{\alpha}}{\alpha \vartheta_{h r, t} W_{t+1} N_{t+1}}\right]^{\frac{1}{\alpha-1}}+ \\
& \frac{(1-\rho)}{\vartheta_{l r, t}} E_{t}\left[\frac{(1-\alpha)\left(1+R_{t}^{l f}\right) K_{t+1}^{\alpha}}{\alpha \vartheta_{l r, t} W_{t+1} N_{t+1}}\right]^{\frac{1}{\alpha-1}}
\end{aligned}
$$

We assume commercial banks are not keen to give out loans to high risk borrowers because they are associated with a lower probability of success, which reduces the banks' expected profits. The banks, however, are not able to distinguish between the two types of borrowers a priori because high risk borrowers have the incentive to mimic the behaviour of low risk borrowers in order to enhance their chances of accessing the FFS loans. Against this behaviour among potential borrowers, therefore, total revealed demand for loans in the FFS is given by:

$$
\begin{aligned}
L_{t}^{a d f}= & \frac{\rho}{\vartheta_{l r, t}} E_{t}\left[\frac{(1-\alpha)\left(1+R_{t}^{l f}\right) K_{t+1}^{\alpha}}{\alpha \vartheta_{l r, t} W_{t+1} N_{t+1}}\right]^{\frac{1}{\alpha-1}} \\
& \frac{(1-\rho)}{\vartheta_{l r, t}} E_{t}\left[\frac{(1-\alpha)\left(1+R_{t}^{l f}\right) K_{t+1}^{\alpha}}{\alpha \vartheta_{l r, t} W_{t+1} N_{t+1}}\right]^{\frac{1}{\alpha-1}} \\
L_{t}^{a d f}= & \frac{1}{\vartheta_{l r, t}} E_{t}\left[\frac{(1-\alpha)\left(1+R_{t}^{l f}\right) K_{t+1}^{\alpha}}{\alpha \vartheta_{l r, t} W_{t+1} N_{t+1}}\right]^{\frac{1}{\alpha-1}}
\end{aligned}
$$

In the absence of information that distinguishes the types, banks resort to credit rationing, turning down some loan applicants even if they are willing to pay a relatively high price (Stiglitz and Weiss, 1981). Indeed when formal credit markets are imperfect due to asymmetric information, credit rationing is the most common practice to minimise banks' exposure to risk (Dasgupta, 2004). We assume the commercial banks can only supply a fraction $\varpi$ of the revealed demand for FFS loans. We further assume $\varpi_{t}$ is endogenously determined within the banks' profit maximisation framework. Following the absence of information that identifies the types of potential borrowers, commercial banks decide to take a safe position by assuming the worst case scenario i.e. that all potential borrowers are high risk. The 
supply function for FFS loans, therefore, is given by:

$$
L_{t}^{s f}=\frac{\varpi_{t}}{\vartheta_{h r, t}} E_{t}\left[\frac{(1-\alpha)\left(1+R_{t}^{l f}\right) K_{t+1}^{\alpha}}{\alpha \vartheta_{h r, t} W_{t+1} N_{t+1}}\right]^{\frac{1}{\alpha-1}}
$$

The loans given out by commercial banks to firms in the formal credit market $\left(L_{t}^{f}\right)$ are converted from household deposits $\left(D_{t}\right)$ and borrowing from the central bank $\left(L_{t}^{c b}\right)$. For simplicity, we assume there is no liquidity reserve requirement (LRR) i.e. all the deposits can be converted into loans. The intermediation technology is assumed to be given by ${ }^{5}$ :

$$
L_{t}^{s f}=D_{t}+L_{t}^{c b}
$$

The commercial banks' profit maximisation problem is described as:

$$
\max _{\substack{a d f \\ L_{t}^{a d}, \varpi_{t}}} \varpi_{t}\left(1+R_{t}^{l f}\right) L_{t}^{a d f}+D_{t}+L_{t}^{c b}-\varpi_{t} L_{t}^{a d f}-\left(1+R_{t}^{d f}\right) D_{t}-\left(1+R_{t}^{n r}\right) L_{t}^{c b}
$$

subject to $L_{t}^{a d f} \leq D_{t}+L_{t}^{c b}$, which reduces to:

$$
\max _{L_{t}^{a d f}, \varpi_{t}} \varpi_{t} R_{t}^{l f} L_{t}^{a d f}-R_{t}^{d f} D_{t}-R_{t}^{n r} L_{t}^{c b} \text { subject to } L_{t}^{a d f} \leq D_{t}+L_{t}^{c b}
$$

Taking FOCs with respect to $L_{t}^{a d f}, D_{t}$ and $L_{t}^{c b}$ and solving for $\varpi_{t}$, we obtain:

$$
\begin{aligned}
\ell_{t} & =\varpi_{t} R_{t}^{l f}=R_{t}^{n r}=R_{t}^{d f} \\
\varpi_{t} & =\frac{R_{t}^{d f}}{R_{t}^{l f}}=\frac{R_{t}^{n r}}{R_{t}^{l f}}
\end{aligned}
$$

where $\ell_{t}$ is a Lagrangian multiplier. Equation (22) states that in equilibrium, the cost of funds from the different sources (household deposits and borrowing from the central bank) will be equal (i.e. $\left.R_{t}^{n r}=R_{t}^{d f}\right)$ and they will be proportional to the return on loans $\left(\varpi R_{t}^{l f}\right)$. Alternatively, equation (23) can be interpreted as stating that the proportion of total demand for FFS loans that is satisfied by the commercial banks is equal to the ratio of the cost of funds from the two identified sources.

\footnotetext{
${ }^{5}$ This can also be seen as a simplified representation the banks' balance sheets with assets on the left hand side and liabilities on the right.
} 


\subsubsection{Informal Financial Sector}

Loans in the IFS are provided by moneylenders ${ }^{6}$. The self selection demand for IFS credit is given by:

$$
L_{t}^{a d i}=\frac{\rho}{\vartheta_{h r, t}} E_{t}\left[\frac{(1-\alpha)\left(1+R_{t}^{l i}\right) q K_{t+1}^{\alpha}}{\alpha \vartheta_{h r, t} W_{t+1} N_{t+1}}\right]^{\frac{1}{\alpha-1}}+\frac{(1-\rho)}{\vartheta_{l r, t}} E_{t}\left[\frac{(1-\alpha)\left(1+R_{t}^{l i}\right) q K_{t+1}^{\alpha}}{\alpha \vartheta_{l r, t} W_{t+1} N_{t+1}}\right]^{\frac{1}{\alpha-1}}
$$

Like commercial banks, moneylenders also face a pool of high and low risk borrowers. However, unlike the banks, the moneylenders are able to identify the risk levels of specific borrowers. Achievement of this feat owes to the localisation of moneylending to communities within the neighbourhood of the lenders, which makes risk-level information readily available. The residual demand for credit in the FFS is defined by equation (25) as the total self-selection demand for loans in the FFS (equation (17)) less the proportion of revealed demand for FFS loans that succeeds in getting loans from the commercial banks (equation (19)). We assume the type of each potential borrower is correctly identified by moneylenders as given by:

$$
\begin{aligned}
L_{t}^{r f}= & \frac{\rho}{\vartheta_{h r, t}} E_{t}\left[\frac{(1-\alpha)\left(1+R_{t}^{l f}\right) K_{t+1}^{\alpha}}{\alpha \vartheta_{h r, t} W_{t+1} N_{t+1}}\right]^{\frac{1}{\alpha-1}}+\frac{(1-\rho)}{\vartheta_{l r, t}} E_{t}\left[\frac{(1-\alpha)\left(1+R_{t}^{l f}\right) K_{t+1}^{\alpha}}{\alpha \vartheta_{l r, t} W_{t+1} N_{t+1}}\right]^{\frac{1}{\alpha-1}}- \\
& \frac{\varpi_{t} \rho}{\vartheta_{h r, t}} E_{t}\left[\frac{(1-\alpha)\left(1+R_{t}^{l f}\right) K_{t+1}^{\alpha}}{\alpha \vartheta_{h r, t} W_{t+1} N_{t+1}}\right]^{\frac{1}{\alpha-1}}-\frac{\varpi_{t}(1-\rho)}{\vartheta_{l r, t}} E_{t}\left[\frac{(1-\alpha)\left(1+R_{t}^{l f}\right) K_{t+1}^{\alpha}}{\alpha \vartheta_{l r, t} W_{t+1} N_{t+1}}\right]^{\frac{1}{\alpha-1}} \\
L_{t}^{r f}= & {\left[\frac{\rho}{\vartheta_{h r, t}}\left(\frac{1}{\vartheta_{h r, t}}\right)^{\frac{1}{\alpha-1}}+\frac{(1-\rho)}{\vartheta_{l r, t}}\left(\frac{1}{\vartheta_{l r, t}}\right)^{\frac{1}{\alpha-1}}-\frac{\varpi_{t} \rho}{\vartheta_{h r, t}}\left(\frac{1}{\vartheta_{h r, t}}\right)^{\frac{1}{\alpha-1}}-\frac{\varpi_{t}(1-\rho)}{\vartheta_{l r, t}}\left(\frac{1}{\vartheta_{l r, t}}\right)^{\frac{1}{\alpha-1}}\right] } \\
& E_{t}\left[\frac{(1-\alpha)\left(1+R_{t}^{l f}\right) K_{t+1}^{\alpha}}{\alpha W_{t+1} N_{t+1}}\right]^{\frac{1}{\alpha-1}}
\end{aligned}
$$

\footnotetext{
${ }^{6}$ We emphasize that the term moneylenders is not used to distinctly refer to the usury market, but rather as a blanket reference to all creditors in the IFS, including the moneylenders themselves, traders, landlords, estate owners and grain millers, inter alia.
} 


$$
\begin{aligned}
L_{t}^{r f}= & {\left[\left(\frac{1}{\vartheta_{h r, t}}\right)^{\frac{1}{\alpha-1}}\left(\frac{\rho\left(1-\varpi_{t}\right)}{\vartheta_{h r, t}}\right)+E_{t}\left(\frac{1}{\vartheta_{l r, t}}\right)^{\frac{1}{\alpha-1}}\left(\frac{(1-\rho)\left(1-\varpi_{t}\right)}{\vartheta_{l r, t}}\right)\right] } \\
& {\left[\frac{(1-\alpha)\left(1+R_{t}^{l f}\right) K_{t+1}^{\alpha}}{\alpha W_{t+1} N_{t+1}}\right]^{\frac{1}{\alpha-1}} }
\end{aligned}
$$

Aggregate demand for loans in the IFS is given by the sum of equations (24) and (25):

$$
\begin{aligned}
& L_{t}^{a d i}=\frac{\rho}{\vartheta_{h r, t}} E_{t}\left[\frac{(1-\alpha)\left(1+R_{t}^{l i}\right) q K_{t+1}^{\alpha}}{\alpha \vartheta_{h r, t} W_{t+1} N_{t+1}}\right]^{\frac{1}{\alpha-1}}+\frac{(1-\rho)}{\vartheta_{l r, t}} E_{t}\left[\frac{(1-\alpha)\left(1+R_{t}^{l i}\right) q K_{t+1}^{\alpha}}{\alpha \vartheta_{l r, t} W_{t+1} N_{t+1}}\right]^{\frac{1}{\alpha-1}}+ \\
& {\left[\left(\frac{1}{\vartheta_{h r, t}}\right)^{\frac{1}{\alpha-1}}\left(\frac{\rho\left(1-\varpi_{t}\right)}{\vartheta_{h r, t}}\right)+\left(\frac{1}{\vartheta_{l r, t}}\right)^{\frac{1}{\alpha-1}}\left(\frac{(1-\rho)\left(1-\varpi_{t}\right)}{\vartheta_{l r, t}}\right)\right]} \\
& {\left[\frac{(1-\alpha)\left(1+R_{t}^{l f}\right) K_{t+1}^{\alpha}}{\alpha W_{t+1} N_{t+1}}\right]^{\frac{1}{\alpha-1}}} \\
& L_{t}^{a d i}=\left[\frac{(1-\alpha)\left(1+R_{t}^{l i}\right) q K_{t+1}^{\alpha}}{\alpha W_{t+1} N_{t+1}}\right]^{\frac{1}{\alpha-1}}\left[\frac{\rho}{\vartheta_{h r, t}}\left(\frac{1}{\vartheta_{h r, t}}\right)^{\frac{1}{\alpha-1}}+\frac{(1-\rho)}{\vartheta_{l r, t}}\left(\frac{1}{\vartheta_{l r, t}}\right)^{\frac{1}{\alpha-1}}+\right. \\
& \left.\left(\frac{1}{\vartheta_{h r, t}}\right)^{\frac{1}{\alpha-1}}\left(\frac{\rho\left(1-\varpi_{t}\right)}{\vartheta_{h r, t}}\right)+\left(\frac{1}{\vartheta_{l r, t}}\right)^{\frac{1}{\alpha-1}}\left(\frac{(1-\rho)\left(1-\varpi_{t}\right)}{\vartheta_{l r, t}}\right)\right] \\
& L_{t}^{a d i}=E_{t}\left[\frac{(1-\alpha)\left(1+R_{t}^{l i}\right) q K_{t+1}^{\alpha}}{\alpha W_{t+1} N_{t+1}}\right]^{\frac{1}{\alpha-1}}\left[\left(\frac{\rho}{\vartheta_{h r, t}}\right)\left(\frac{1}{\vartheta_{h r, t}}\right)^{\frac{1}{\alpha-1}}(2-\varpi)+\right. \\
& \left.\left(\frac{(1-\rho)}{\vartheta_{l r, t}}\right)\left(\frac{1}{\vartheta_{l r, t}}\right)^{\frac{1}{\alpha-1}}(2-\varpi)\right] \\
& L_{t}^{a d i}=\left(2-\varpi_{t}\right) E_{t}\left[\frac{(1-\alpha)\left(1+R_{t}^{l i}\right) q K_{t+1}^{\alpha}}{\alpha W_{t+1} N_{t+1}}\right]^{\frac{1}{\alpha-1}}\left[\left(\frac{\rho}{\vartheta_{h r, t}}\right)\left(\frac{1}{\vartheta_{h r, t}}\right)^{\frac{1}{\alpha-1}}+\right. \\
& \left.\left(\frac{(1-\rho)}{\vartheta_{l r, t}}\right)\left(\frac{1}{\vartheta_{l r, t}}\right)^{\frac{1}{\alpha-1}}\right]
\end{aligned}
$$




\subsection{Monetary Authorities}

To identify how monetary policy is conducted in QEMEs, we first experiment with a forward looking monetary policy rule that treats the bank rate $\left(R_{t}^{n r}\right)$ as an operating tool of monetary policy. The forward-looking specification allows the central bank to consider a broad array of information to form beliefs about the future condition of the economy (Clarida, Gali and Gertler, 2000). The rule calls for adjustment of the bank rate based on the return on investment, the expected change in output and expected inflation:

$$
R_{t}^{n r}=\chi_{1} R_{t}^{r r}+\chi_{2} \Delta Y^{e}+\left(1-\chi_{2}\right) \pi^{e}+\mu
$$

where $R_{t}^{r r}$ is the real rat of interest or return on investment, $\Delta Y^{e}$ is expected change in output i.e. $\Delta Y^{e}=E\left(Y_{t+1}\right)-Y_{t}, \pi^{e}$ is expected rate of inflation defined as the expected difference between real and nominal interest rates in the next period and $\mu$ is a disturbance term assumed to be iid. Since our model is in discreet time, we postulate that the marginal productivity of capital in the next period is equal to the rate of interest (see Carlstrom and Fuerst, 2003; Benhabib, Carlstrom and Fuerst, 2005) as given by:

$$
R_{t}^{r r}=\alpha e^{A_{t+1}} K_{t+1}^{\alpha-1} N_{t+1}^{1-\alpha}
$$

\subsection{Market Equilibrium}

In equilibrium, clearing of the final goods market implies that aggregate production is equal to demand for household consumption and private investment:

$$
Y_{t}=C_{t}+I_{t}
$$

where $I_{t}=K_{t+1}$. We assume that money is required for all transactions in the goods market. In equilibrium, therefore, the following equality will hold:

$$
P_{t} C_{t}=M_{t}
$$

Equation (30) is an identity illustrating an ex-post equilibrium position connoting that prices operate only on the real side of the market. Since we have used $N_{t}$ to represent labour supply by the household as well as labour demand by the firm, we have implicitly assumed clearing of the labour market. The equilibrium wage is determined by the market according to equations (5) and (14). The bank rate is determined by the monetary policy reaction function 
in equation (27). Commercial bank deposit and and IFS interest rates are endogenously determined. Base lending rates are determined by loading a fixed mark-up over the bank rate. Self selection demand for FFS and IFS loans is given by equations (15) and (16), in that order. Equations (19) and (26) represent loans supplied by the formal and informal financial sectors, respectively. Equilibrium in the two markets follow the simultaneous equation solution of the two equations, which takes into account the spill-over of demand from the FFS satisfied by the supply in the IFS. The sum of equations (19) and (26) determines the level of capital accumulation in the economy.

We assume prices adjust to equate supply and demand in every market simultaneously (see Mankiw, 1989). We further assume that money supply is exogenous. Interest rates and the price level adjust to equate the supply and demand in the money market.

\section{Simulation Results and Inferences}

The model is solved using DYNARE. Calibrated parameter and steady state values are summarised in Table 1 in the Appendix. We focus our attention on two shocks, viz., a positive production technology shock characterised by an unexpected improvement in production technology and a monetary policy shock identified by an unanticipated increase in the bank rate. In each case, we experiment with two distinct risk factors or success rates for high risk borrowers. Figures 1 and 2 show the impact of a positive production technology shock on various economic indicators when the success rate is nearly zero (0.00001) and 0.2, respectively. Figures 3 and 4 repeat the experiment but for a monetary policy shock.

\subsection{Production Technology Shock $\left(\vartheta_{h r}=0.00001\right)$}

An unanticipated improvement in production technology with the rate of success for high risk borrowers nearly zero $\left(\vartheta_{h r}=0.00001\right)$, as illustrated in Figure 1, causes a decline in marginal costs across all firms leading to a jump in output and a decline in expected prices. In line with the assumption of flexible prices, firms fully adjust their prices with the result that aggregate demand rises proportionately to the increase in productivity, leading to a gradual increase in employment (after an initial dip). Since the shock causes an improvement in the marginal productivity of capital, which is equal to the instantaneous interest rate (see Carlstrom and Fuerst, 2003; Benhabib et al., 2005), we observe that our measure of the real interest rate goes up together with all nominal interest rates in the FFS. Holding the risk of default constant, interest rates in the IFS adjust upwards as well, in line with the lenders' 
risk hypothesis (see Basu, 1997) ${ }^{7}$.

As a direct consequence of the improvement in technology, labour productivity increases, consequently pushing wage rates upwards. Coupled with the increase in employment, the higher wage rates lead to a rise in households' financial resources, which results in an increase in loans supplied by moneylenders. IFS loans, therefore, go up. Commercial banks respond to the higher output by expanding their customer base, which results into a rise in FFS loans, albeit marginally. Consistent with the higher interest rates, the commercial banks also increase the proportion of total demand for FFS loans that succeeds in getting the loans. Since capital stock depends on the sum of formal and informal financial sector loans, inter alia, the increase in lending by commercial banks and moneylenders is followed by a rise in capital stock.

\subsection{Production Technology Shock $\left(\vartheta_{h r}=0.2\right)$}

Figure 2 shows the impact of a positive production technology shock when the rate of success for high risk borrowers is relatively high at 0.2 . In contrast to the case in the previous section, it is shown in Figure 2 that a higher rate of success for high risk borrowers causes a larger increase in FFS loans since more entrepreneurs are now willing to take the risk of investing in a business. IFS loans, on the other hand, do not change since all borrowers in this sector are fully identified by the lenders, implying that their loss function at every level of risk remains unchanged. The net position is a larger increase in capital stock and output. The initial dip in employment observed in 1 lessens as the rate of success for the high risk borrowers increases and at $\vartheta_{h r}=0.2$, it completely reverses, turning into an initial jump in employment that gradually returns to equilibrium.

\subsection{Monetary Policy Shock $\left(\vartheta_{h r}=0.00001\right)$}

Figure 3 shows impulse response functions of a monetary policy shock when the rate of success for high risk borrowers is nearly zero (i.e. 0.00001). The shock causes an increase in base lending rates and expected forward inflation. Facing higher expected prices, households smoothen their consumption by reducing their consumption expenditures while firms respond to the expected lower sales by cutting down on production, employment and wage rates. Accordingly, capital formation and subsequently demand for both formal and informal financial sectors loans decline. The decline in IFS loans is reinforced by the lower wages and

\footnotetext{
${ }^{7}$ The lender's risk hypothesis states that lenders in the IFS face a positive risk of default. Once the risk is taken into account, the effective interest rate in the IFS equates to the FFS rate of interest.
} 
employment, which reduce households' financial resources, consequently lowering loanable funds for moneylenders. Though commercial banks increase the proportion of total demand for FFS loans that succeeds in getting the loans following the relatively higher lending rates, total FFS loans decline as a result of the general decline in the demand for loans.

Moneylenders initially reduce their lending rates, possibly because the reduction in their capacity to give out loans is proportionately lower than the decline in demand for IFS loans i.e. at the pre-shock lending rates, the moneylenders have excess supply of loans, ceteris paribus. Since IFS loans and commercial bank deposits are substitutes to households, the excess IFS loanable funds are deposited in commercial banks, leading to a decline in commercial bank deposit rates as well. This decline in commercial bank deposit rates may also be attributed to the banks' inability to lend, leaving them with no incentive to attract deposits because of the absence of any outlet for them.

\subsection{Monetary Policy Shock $\left(\vartheta_{h r}=0.2\right)$}

Figure 4 shows impulse responses of a monetary policy shock on selected macroeconomic indicators following an increase in the success rate of high risk borrowers to 0.2 from 0.00001 . At this higher success rate, an unexpected increase in the bank rate causes a larger decline in the demand for loans, both in the formal and informal financial sectors, leading to a larger drop in capital stock, which corresponds to a larger decline in employment and output. Expected forward prices go up by a larger margin than in the case where $\vartheta_{h r}=0.00001$, causing a larger decline in consumption, output, employment, wages, lending and capital formation. While the base lending rates remain unchanged, commercial bank deposit rates and IFS lending rates decline by a larger margin relative to the case of a lower success rate for high risk borrowers. A larger decline in the proportion of the total demand for FFS loans that succeeds in getting the loans leads to a further decline in FFS loans.

\subsection{Inferences}

The model reveals that though formal and informal financial sector loans may be substitutes in the borrowing firm's utility function, they are in effect complementary in the aggregate. A complementary credit link exists when growth in demand for credit from one sector is accompanied by an increase in demand for credit from the other sector (Chipeta and Mkandawire, 1991). This implies that an increase in capital formation financed by FFS credit creates additional productive capacity that can be utilised only with IFS credit in order to maintain the economy at an equilibrium level (see Aryeetey, 1992; Chipeta and Mkan- 
dawire, 1992). Since the IFS provides additional finance to firms in excess of what comes from the FFS, increasing the use of FFS credit increases the demand for credit in the IFS.

The model further demonstrates that the response of FFS loans to a positive production technology shock is sensitive to the rate of success for high risk borrowers while the response of IFS loans is not. An increase in the rate of success for high risk borrowers motivates potential entrepreneurs to borrow from commercial banks and invest in businesses as the risk of failure is now relatively low. Since commercial banks are not able to distinguish between the types of borrowers, an increase in the success rate of high risk borrowers increases the banks' expected profits. For this reason, more FFS loans are given out. In the IFS, on the other hand, the types of borrowers are fully identified, indicating that a change in the success rate of high risk borrowers does not change the risk profile of the potential borrowers in the sector. Accordingly, moneylenders find no reason to adjust the amount of loans given out.

The model also illustrates that both formal and informal financial sector loans are sensitive to high risk borrowers' success rates in their response to a monetary policy shock. Following an unexpected increase in the base lending rate, we observe that higher success rates for high risk borrowers are associated with larger declines in the demand for loans in both sectors.

In addition, the model shows that interest rates in the IFS are not necessarily driven by FFS interest rates. While interest rates in the two sectors were observed to change together in the same direction following a positive production technology shock, the same is not observed with a monetary policy shock. The implication of this finding is that the IFS may frustrate monetary policy. We observe, for instance, from the impulse responses of the monetary policy shock that a contractionary monetary policy is partly offset by a subdued decline in IFS lending. While formal and informal financial sector loans remain complementary, the

decline in IFS loans following a contractionary monetary policy is lessened by a drop in IFS interest rates.

Finally, in line with business cycle stylised facts, the model shows that lending, both in the formal and informal financial sectors, capital formation, consumption and output follow the pattern of business cycles.

\section{Summary and Conclusion}

This paper set out to investigate the interaction of formal and informal financial sectors and to examine how economic activity is affected. Commencing with the observation that the IFS in QEMEs is large and plays a non-trivial role in defining the direction of economic activity, we developed a four-sector macromonetary DSGE model for analysis. The model 
demonstrate that while formal and informal sector loans may be substitutes in a borrower's utility function, they are in the aggregate complementary. Given that the IFS provides additional finance to borrowers in excess of the FFS loan supply, increasing the use of FFS credit increases the demand for credit in the IFS (see Aryeetey, 1992; Chipeta and Mkandawire, 1992). We also show that interest rates in the IFS may not necessarily be

driven by FFS interest rates. While the two may move together in some instances, they may also move in diametrically opposite directions in other instances. It cannot, therefore, be generalised that the IFS promotes or frustrates monetary policy. Finally, in line with business cycle stylised facts, the model shows that lending, both in the formal and informal financial sectors, capital formation, consumption and output follow the pattern of business cycles.

\section{References}

Acharya, S. and Madhura, S. (1983). Informal credit markets and black money: Do they frustrate monetary policy?, Economic and Political Weekly 8: 1751-1756.

African Development Bank, A. (1994). African development report, African Development .

Ambler, S. and Paquet, A. (1994). Stochastic depreciation and the business cycle, International Economic Review. 44: 101-116.

Aryeetey, E. (1992). The relationship between formal and informal sectors in the financial market in ghana, AERC Research Paper Series 10.

Aryeetey, E. (1994). Financial integration and development in sub-saharan: A study of informal finance in ghana, Overseas Development Institute Working Paper Series WP/78.

Aryeetey, E. (2008). From informal finance to formal finance in sub-saharan africa: Lessons from linkage efforts, AERC/IMF African Finance for the 21st Century Unpublished Manuscript.

Atieno, R. (2001). Formal and informal institutions' lending policies and access to credit by small-scale enterprises in kenya: An empirical assessment, $A E R C$ Research Paper Series RP111: 1-46.

Bagachwa, M. (1995). Financial integration and development in sub-saharan africa: A study of informal finance in tanzania, ODI Working Paper Series .

Basu, K. (1997). Analytical Development Economics: The Less Developed Economy Revisited, revised edition edn, Massachussetts: The MIT Press. 
Bell, C. (1990). Interactions between institutional and informal credit agencies in rural india, The World Bank Economic Review 4(3): 297-327.

Benhabib, J., Carlstrom, C. and Fuerst, T. (2005). Introduction to monetary policy and capital accumulation, Journal of Economic Theory 123: 1-3.

Bolnick, B. (1992). Moneylenders and informal financial markets in malawi, World Development 20(1): 57-68.

Carlstrom, C. and Fuerst, T. (2003). Investment and interest rate policy: A discrete time analysis, Federal Reserve Bank of Cleveland Working Paper Series WP/03/20: 1-24.

Chipeta, C. (1998). Improving the intermediation role of the informal financial sector in africa, Paper Presented at the United Nations Asia-Africa High-Level Workshop on Advancing Financial Intermediation in Africa, Port Louis, Mauritius, 20-22 April, 1998

Chipeta, C. and Mkandawire, M. (1991). The informal financial sector and macroeconomic adjustment in malawi, AERC Research Paper Series RP4: 1-58.

Chipeta, C. and Mkandawire, M. (1992). Links between the informal and formal /semi-formal financial sectors in malawi, AERC Research Paper Series 14: 1-39.

Clarida, R., Gali, J. and Gertler, M. (2000). Monetary policy rules and macroeconomic stability: Evidence and some theory, The Qauarterly Journal of Economics February: 147-180.

Dasgupta, B. (2004). Capital accumulation in the presence of informal credit constraints: Does the incentive mechanism work better than credit rationing under asymmetric information?, University of Connecticut, Department of Economics Working Paper Series 2004-32.

Mankiw, G. (1989). Real business cycles: A new keynesian perspective, Journal of Economic Perspectives 3(3): 79-90.

Mankiw, G. (2006). The macroeconomist as scientist and engineer, Journal of Economic Perspectives 20(4): 29-46.

Peiris, S. and Saxegaard, M. (2007). An estimated dsge model for monetary policy analysis in low income countries, IMF Working Paper Series WP/07/282.

Rahman, A. (1992). The informal financial sector in bangladesh: An appraisal of its role in development, Development and Change 23: 147-168. 
Soyibo, A. (1997). The informal financial sector in nigeria: Characteristics and relationship with the formal sector, Development Policy Review 15: 5-22.

Steel, W., Aryeetey, E., Hettige, H. and Nissanke, M. (1997). Informal financial markets under liberalisation in four african countries, World Development 25(5): 817-830.

Stiglitz, J. and Weiss, A. (1981). Credit rationing in markets with imperfect information, The American Economic Review 71(3): 393-410.

Sundaram, K. and Pandit, V. (1984). Informal credit markets, black money and monetary policy: Some analytical and empirical issues, Economic and Political Weekly 19: 695$677 \& 679-682$.

Tovar, C. (2008). Dsge models and central banks, BIS Working Paper Series WP No. 258.

Woodford, M. (2003). Interest and prices: Foundations of a theory of monetary policy. 
Appendix: Tables and Figures 
Table 1: Calibrated Parameter and Steady State Values

\begin{tabular}{|l|l|r|}
\hline Parameter & Description & Value \\
\hline$\alpha$ & Output elasticity of capital & 0.37 \\
\hline$\beta$ & Consumer subjective intertemporal discount factor & 0.99 \\
\hline$\delta$ & Depreciation rate & 1 \\
\hline$\eta$ & Autoregressive process for the technology factor & 0.91 \\
\hline$\Gamma$ & Consumption parameter & 1 \\
\hline$q$ & Probability of loan repayment in the IFS & 0.85 \\
\hline$\Phi$ & Leisure parameter & 3 \\
\hline$\phi$ & Lagrangian multiplier in a firm's cost minimisation function & 0.8 \\
\hline$\rho$ & Proportion of high risk borrowers & 0.15 \\
\hline$\vartheta_{h r}$ & Risk factor (rate of success) for high risk borrowers & 0.98 \\
\hline$\vartheta_{l r}$ & Risk factor (rate of success) for low risk borrowers & 0.1 \\
\hline$\zeta$ & Mark-up over the bank rate to obtain base lending rate & 0.99 \\
\hline$\chi_{1}$ & Factor of inertia in the base lending rate & 0.99 \\
\hline$\chi_{2}$ & Weight of expected change in output in the monetary policy rule & 0.8 \\
\hline$C$ & Initial value of consumption & 0.2 \\
\hline$K$ & Initial value of capital stock & 0.3 \\
\hline$N$ & Initial value of employment & 0.7 \\
\hline$\varpi$ & Initial value of proportion of FFS loan demand that is satisfied & 0.3 \\
\hline$W$ & Initial value of wage rate & 0.075 \\
\hline$R^{d f}$ & Initial value of commercial bank deposit rates & 0.27 \\
\hline$\pi^{e}$ & Initial value of expected inflation & 0.02 \\
\hline$\varepsilon^{A}$ & Initial value of technology shock & 0.02 \\
\hline$m u$ & Initial value of monetary policy shock & 0.2 \\
\hline & & \\
\hline
\end{tabular}


Figure 1: Impulse Responses of a Production Technology Shock when $\vartheta_{h r}=0.00001$
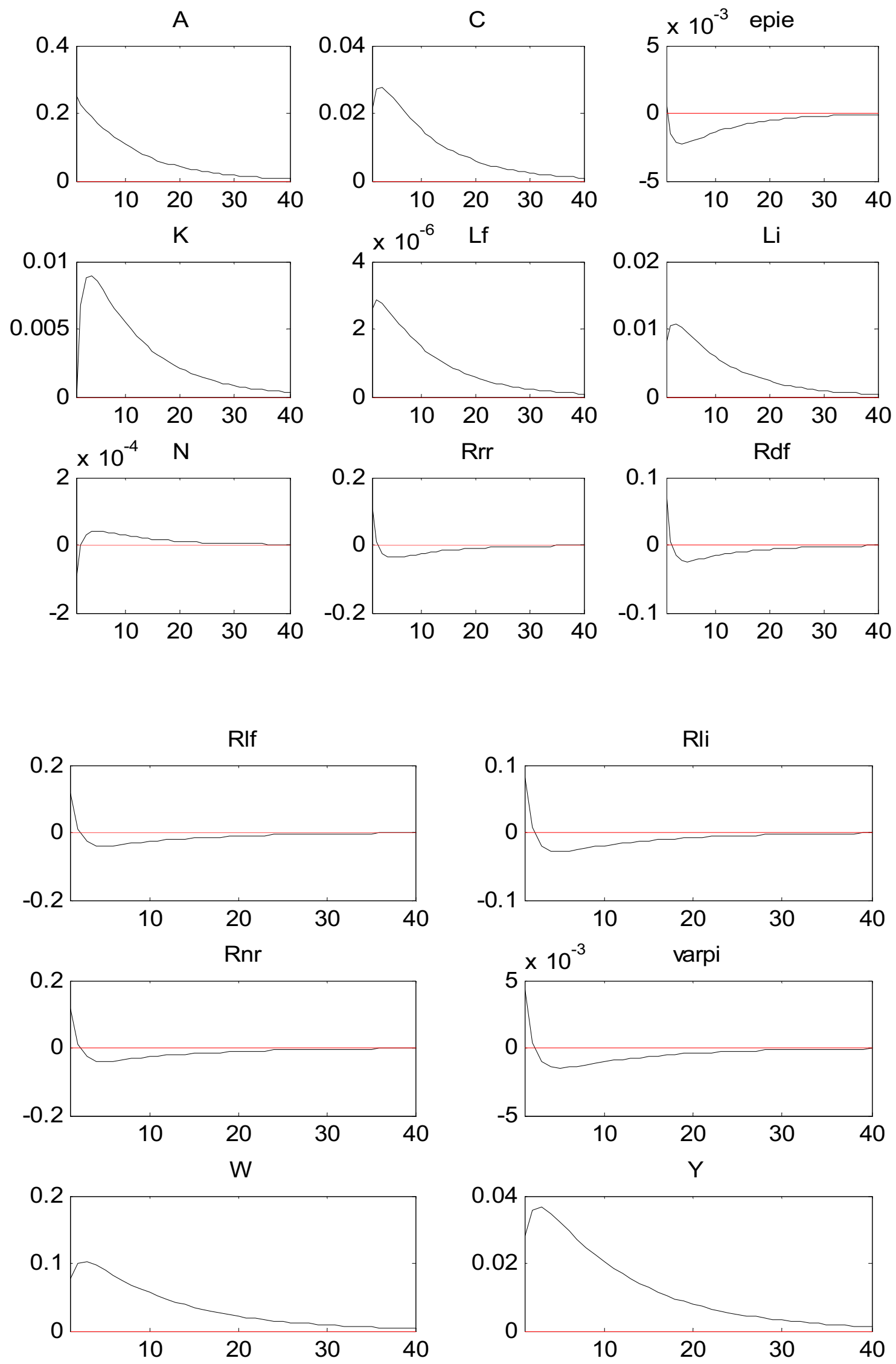
Figure 2: Impulse Responses of a Production technology Shock when $\vartheta_{h r}=0.2$
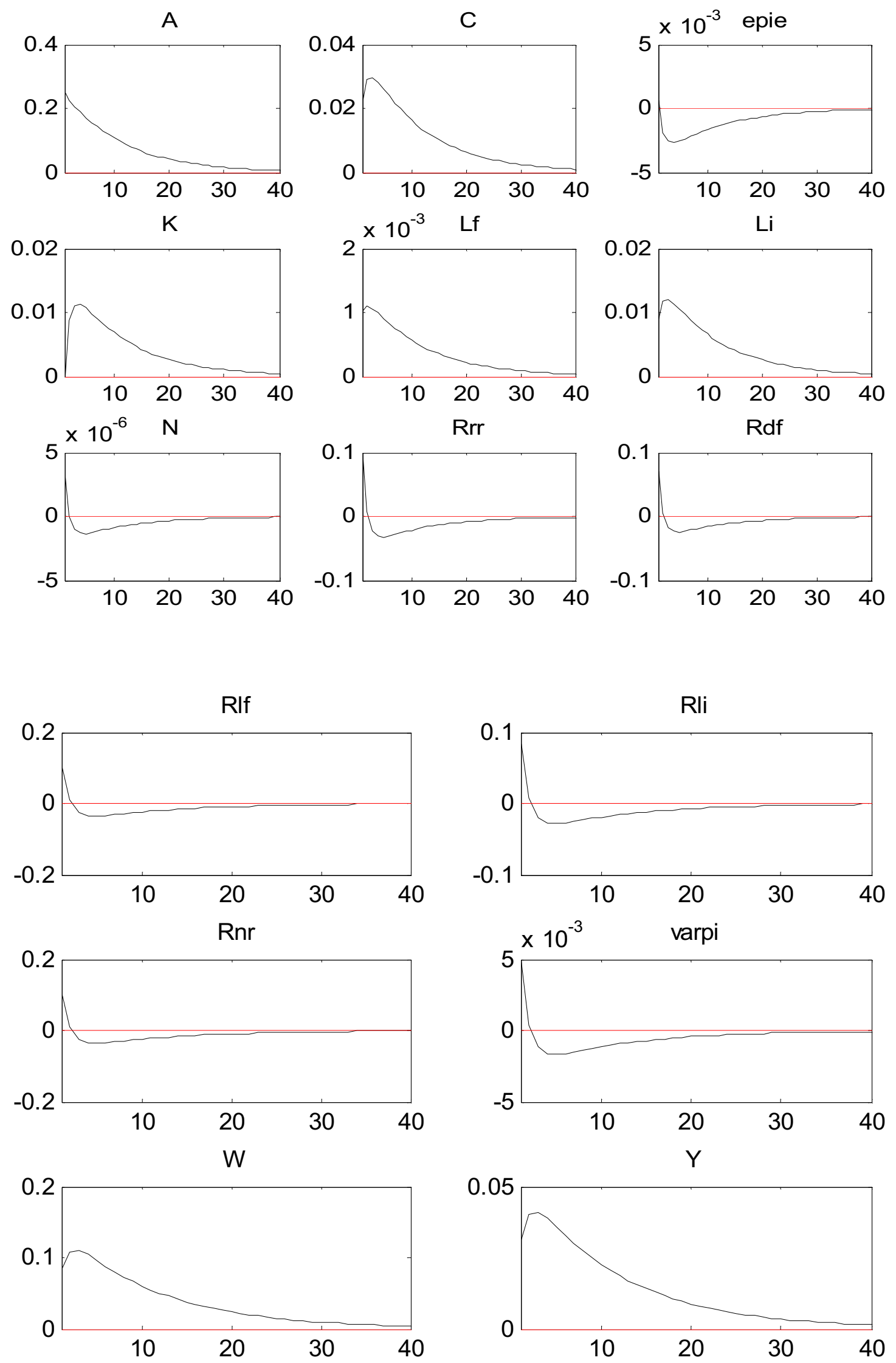
Figure 3: Impulse Responses of a Monetary Policy Shock when $\vartheta_{h r}=0.00001$
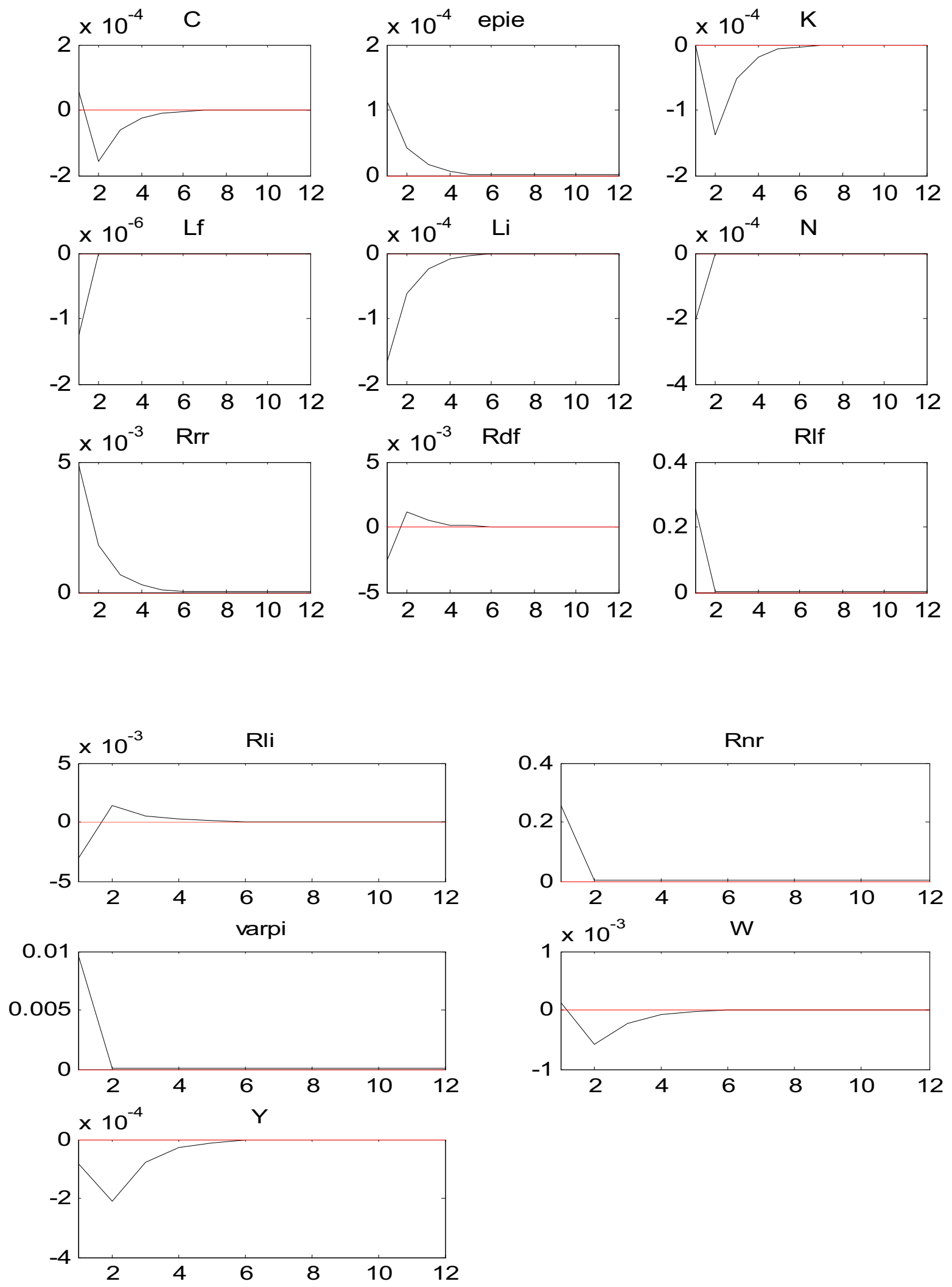
Figure 4: Impulse Responses of a Monetary Policy Shock when $\vartheta_{h r}=0.2$
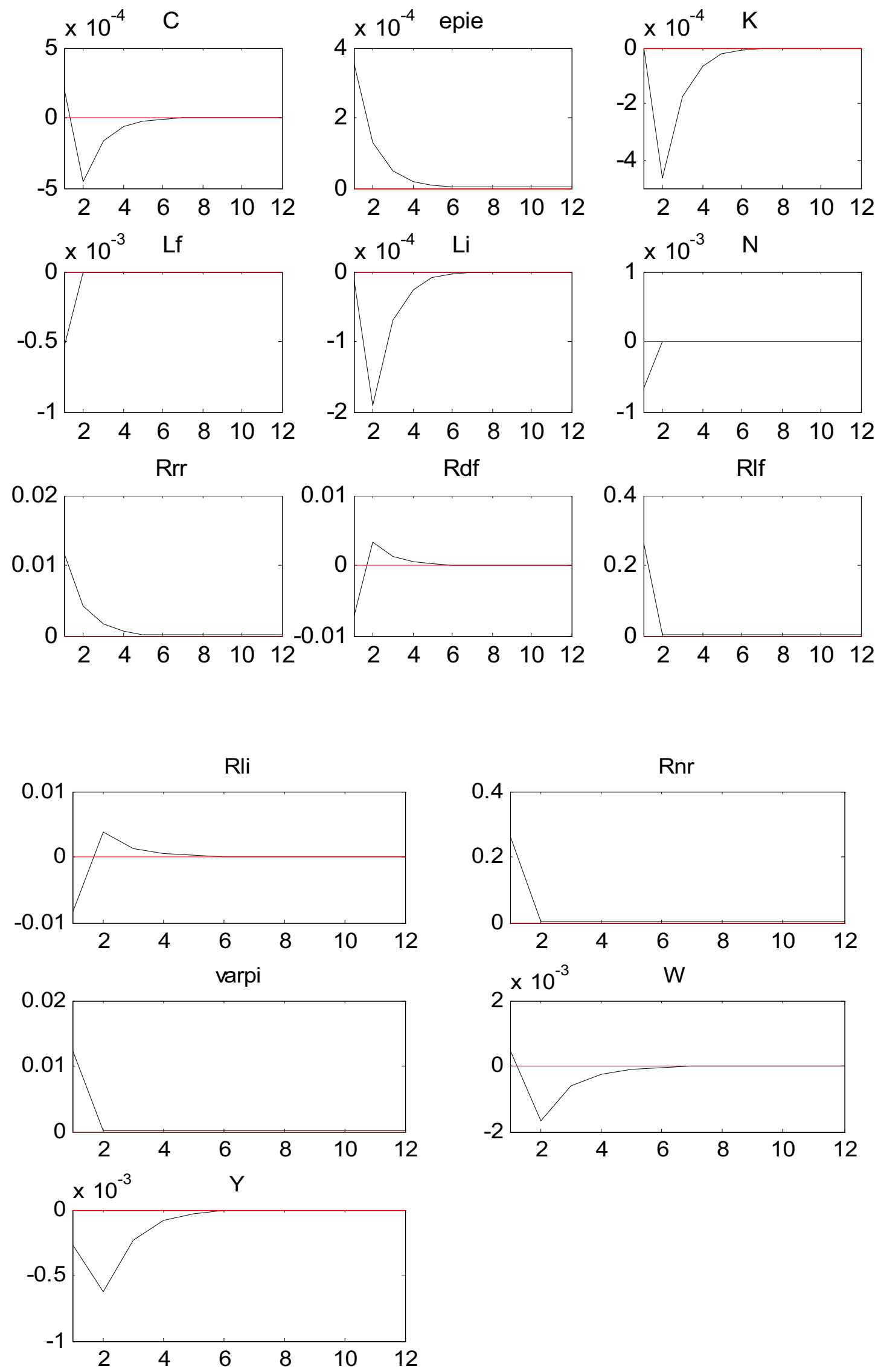